Proceeding Paper

\title{
Assessment of the Physical Properties of the Fuel Pellets Formed from Post-Harvest Sage Waste with the Addition of Rye Bran ${ }^{\dagger}$
}

\author{
Gabriel Siegień *(D), Sławomir Obidziński $(\mathbb{D}$, Małgorzata Kowczyk-Sadowy and Piotr Ławrynowicz
}

check for updates

Citation: Siegień, G.; Obidziński, S.; Kowczyk-Sadowy, M.; Ławrynowicz, P. Assessment of the Physical Properties of the Fuel Pellets Formed from Post-Harvest Sage Waste with the Addition of Rye Bran. Environ. Sci. Proc. 2021, 9, 23. https://doi.org/ 10.3390/environsciproc2021009023

Academic Editors: Dorota Anna Krawczyk, Iwona Skoczko, Antonio Rodero Serrano and Ewa Szatyłowicz

Published: 2 November 2021

Publisher's Note: MDPI stays neutral with regard to jurisdictional claims in published maps and institutional affiliations.

Copyright: (c) 2021 by the authors. Licensee MDPI, Basel, Switzerland. This article is an open access article distributed under the terms and conditions of the Creative Commons Attribution (CC BY) license (https:/ / creativecommons.org/licenses/by/ $4.0 /)$.
Department of Agri-Food Engineering and Environmental Management, Bialystok University of Technology, Wiejska 45E Street, 15-351 Bialystok, Poland; s.obidzinski@pb.edu.pl (S.O.); m.kowczyw@pb.edu.pl (M.K.-S.); piotrlawrynowiczgm@gmail.com (P.Ł.)

* Correspondence: g.siegien@pb.edu.pl; Tel.: +48-(85)-746-96-52

+ Presented at the Innovations-Sustainability-Modernity-Openness Conference (ISMO'21), Bialystok, Poland, 14 May 2021.

Abstract: The paper presents the results of studies on the effect of rye bran addition (from 10 to 20\%) on the course of the granulation process of post-harvest sage waste and on the quality of the obtained granulate (including its fuel properties). The granulation process was tested on the SS-4 test stand, with a P-300 granulator with a "flat matrix-compacting rollers" working system. The addition of rye bran causes a reduction of the power requirement of the granulator (from 3.75 to $3.19 \mathrm{~kW}$ ) and a reduction of physical and bulk density, as well as an increase in its kinetic durability. We determined the higher heating value of sage (at $10 \%$ moisture content), $19.39 \mathrm{MJ} / \mathrm{kg}$, and the lower heating value, $18.17 \mathrm{MJ} / \mathrm{kg}$, thereby allowing us to state its high energy values. The addition of $20 \%$ of rye bran causes a decrease in the higher heating value by $2.07 \%$ and the lower heating value by $2.67 \%$.

Keywords: sage waste; granules; rye bran; energy properties

\section{Introduction}

Due to the depletion of fossil fuel resources, we are forced to reach for ever newer energy sources. Renewable energy based on wind, solar and geothermal energy is becoming increasingly popular. However, the most dynamically developing concept is the use of biomass as the basic carrier of renewable energy sources. Plant waste (straw, wood waste, bark, waste from the food industry) can become such a carrier.

The source of biomass can also be herbal waste, which can be used to produce liquid fuel [1], to produce biogas [2,3], as an additive to the production of vermicompost [4], as a compost component, along with food waste [5], as additives in the production of fodder [6,7], or in the production of packaging [8].

One such herbal waste is post-harvest sage waste. Currently, sage is used more and more in various fields; it is used to produce medical and pharmaceutical preparations, and it is used in cosmetics due to its antimicrobial and antioxidant properties [1-3]. The use of this plant for the above-mentioned purposes leaves plant waste in the form of straw and stems, which can be used to produce pellets, which is confirmed by previous studies $[3,9]$. The effect of the increased processing of sage is the amount of sage waste, which increases from year to year [10]; thereby prompting research on the possibility of its management in a mixture with rye bran, which is a waste in food processing, produced in large quantities and difficult to manage, e.g., for animal husbandry purposes.

The aim of the research was to determine the effect of the addition of rye bran on the course of the granulation process of post-harvest sage waste and on the quality of the obtained granulate (including its fuel properties). 


\section{Research Methodology}

The research used waste in the form of stems and leaf residues from sage and rye bran. The sage straw came from an individual farm in the Kruszyn commune in the province Warmian-Masurian Voivodeship, while the rye bran came from the Romaszówka mill, near Korycin.

The granulation process was tested on the SS- 4 test stand, which consists of a granulator P-300, a power supply meter, and a vibrating feeder. The granulator has a working system with "flat matrix-compacting rollers"; its structure is described in the works [11,12]. During the research, the effect of the addition of rye bran added in the amount of 10,15, and $20 \%$ to post-harvest sage waste on the power requirement of the granulator and the density (bulk and physical) and kinetic durability of the obtained granulate was determined. The amount of additive at the level of 10, 15 and $20 \%$ enabled identification of the trends in the properties of the mixture, which were found on the basis of Obidziński's previous experience [6,9-12].

The granulate bulk density was determined in accordance with the determination of the bulk density in standard solid biofuels [13]. Determination of physical density was performed with the use of a caliper and an AS220/C/2 laboratory balance by RADWAG. The kinetic durability of the granulate was determined in accordance with the standard [14] and the methodology described in the works [11,12], $24 \mathrm{~h}$ after the granulate was produced, using the Holmen tester.

Determination of the higher heating value and lower heating value was carried out in accordance with the [15] standard and the methodology described in [16], using the KL-12Mn calorimeter.

\section{Results}

Table 1 shows the results of the research on the effect of the addition of rye bran on the course of the granulation process of post-harvest sage waste and the quality of the obtained granulate.

Table 1. The effect of the addition of rye bran on the course of the granulation process of post-harvest sage waste, and on the quality of the obtained granulate.

\begin{tabular}{|c|c|c|c|c|c|c|}
\hline $\begin{array}{c}\text { Bran } \\
\text { Content }[\%]\end{array}$ & $\begin{array}{l}\text { Power Requirement of } \\
\text { the Granulator }[\mathrm{kW}]\end{array}$ & $\begin{array}{l}\text { Physical Density } \\
{\left[\mathrm{kg} / \mathrm{m}^{3}\right]}\end{array}$ & $\begin{array}{l}\text { Bulk Density } \\
{\left[\mathrm{kg} / \mathrm{m}^{3}\right]}\end{array}$ & $\begin{array}{c}\text { Kinetic } \\
\text { Durability [\%] }\end{array}$ & $\begin{array}{l}\text { Higher Heating } \\
\text { Value }\left[\mathrm{MJ} / \mathrm{kg}^{1}{ }^{1}\right.\end{array}$ & $\begin{array}{l}\text { Lower Heating } \\
\text { Value }[\mathrm{MJ} / \mathrm{kg}]^{1}\end{array}$ \\
\hline 0 & 3.75 & 1233.99 & 626.24 & 97.17 & 19.39 & 18.16 \\
\hline 10 & 3.57 & 1192.80 & 611.54 & 97.64 & 19.19 & 17.92 \\
\hline 15 & 3.38 & 1177.18 & 583.22 & 98.14 & 19.09 & 17.80 \\
\hline 20 & 3.19 & 1145.05 & 545.16 & 97.01 & 18.99 & 17.68 \\
\hline
\end{tabular}

${ }^{1}$ Values calculated on the basis of the higher heating value and the lower heating value of the raw materials (at $10 \%$ moisture content).

As a result of the research, it was found that the highest power consumption occurred during the granulation of sage waste without the addition of bran, with $3.75 \mathrm{~kW}$. With the increase in the amount of rye bran addition, the power demand decreased by approx. $15 \%$ to $3.19 \mathrm{~kW}$ (with $20 \%$ bran addition).

The addition of rye bran also influenced the physical and bulk density of the produced granules. With increased content of the additive, the physical density decreased from $1233.99 \mathrm{~kg} / \mathrm{m}^{3}$ (granulate without the addition of bran) to the value of $1145.05 \mathrm{~kg} / \mathrm{m}^{3}$ (with $20 \%$ bran addition). In the case of bulk density, the relationship was analogous. The results of the kinetic durability measurements showed that the granules with $15 \%$ bran addition $(98.14 \%)$, showed the highest strength. A further increase in the amount of additive from 15 to $20 \%$ resulted in a decrease in kinetic durability, which may be due to the bad binder properties of rye bran. The average analytical value of the higher heating value of sage waste is $19.39 \mathrm{MJ} / \mathrm{kg}$ and the lower heating value $18.16 \mathrm{MJ} / \mathrm{kg}$ (at $10 \%$ moisture content). 
The conducted research has shown that the tested waste is characterized by energy values similar to other waste of plants: buckwheat husk $(20.12 \mathrm{MJ} / \mathrm{kg})$, alder bark $(20.31 \mathrm{MJ} / \mathrm{kg})$, or rape straw $(20.1 \mathrm{MJ} / \mathrm{kg})[17,18]$. When used in the form of pellets or fuel briquettes, they can become a fully-fledged, cheap, and ecological solid fuel.

\section{Conclusions}

The conducted research allowed us to conclude that post-harvest sage waste may become a potential energy source to produce solid fuels in the form of granules. The determined higher heating value of sage (at a moisture content of $10 \%$ ) of $19.39 \mathrm{MJ} / \mathrm{kg}$, and its lower heating value of $18.16 \mathrm{MJ} / \mathrm{kg}$, allowed for its high energy values to be stated. The addition of rye bran added as a binder during granulation has a positive effect on the granulation process, reducing the power requirement of the granulator and increasing the kinetic durability of the obtained granulate (the highest kinetic durability of $98.14 \%$ was obtained with the addition of $15 \%$ rye bran), and also causes a slight decrease in its physical and bulk density, as well as a higher heating value and lower heating value.

Author Contributions: S.O.: research concept, experiment design, research methodology, and manuscript correction; M.K.-S.: carrying out research, research analysis; G.S.: research analysis, preparation of the manuscript; P.Ł.: performing research, research analysis. All authors have read and agreed to the published version of the manuscript.

Acknowledgments: The work was carried out as part of a team project no. WZ/WB-IIŚ/2020 and financed by the Polish Ministry of Science and Higher Education.

Conflicts of Interest: The authors declare no conflict of interest.

\section{References}

1. Sienkiewicz, A.; Piotrowska-Niczyporuk, A.; Bajguz, A. Fatty Acid Methyl Esters from the Herbal Industry Wastes as a Potential Feedstock for Biodiesel Production. Energies 2020, 13, 3702. [CrossRef]

2. Lewicki, A.; Pilarski, K.; Janczak, D.; Czekała, W.; Rodríguez Carmona, P.C.; Cieślik, M.; Witaszek, K. The Biogas Production From Herbs And Waste From Herbal Industry. J. Res. Appl. Agric. Eng. 2013, 58, 114-117.

3. Kowalska, H. Zrównoważone Technologie Wykorzystanie Roślinnych Produktów Ubocznych. Przem. Spoż. 2018, 1, $28-31$. [CrossRef]

4. Kumari, M.; Kumar, S.; Chauhan, R.S.; Ravikanth, K. Bioconversion of Herbal Industry Waste into Vermicompost Using an Epigeic Earthworm Eudrilus Eugeniae. Waste Manag. Res. J. Sustain. Circ. Econ. 2011, 29, 1205-1212. [CrossRef] [PubMed]

5. Zhou, Y.; Selvam, A.; Wong, J.W.C. Chinese Medicinal Herbal Residues as a Bulking Agent for Food Waste Composting. Bioresour. Technol. 2018, 249, 182-188. [CrossRef] [PubMed]

6. Kowczyk-Sadowy, M.; Piekut, J.; Obidziński, S. Wpływ Dodatku Wycierki Ziemniaczanej Na Proces Zagęszczania Mieszanek Perzu. Przem. Chem. 2018, 97, 737-740. [CrossRef]

7. Obidziński, S. Charakterystyka Aktywności Wody i Parametrów Geometrycznych Odpadów Melisy w Aspekcie Ich Wykorzystania Jako Dodatku Do Pasz. Acta Agrophysica 2013, 20, 113-124.

8. Tulska, E. Możlizwości Zagospodarowania Surowców Odpadowych do Produkcji Opakowań; Wydawnictwo Fundacji Promovendi: Łódź, Poland, 2018; ISBN 978-83-950109-5-8.

9. Obidziński, S. Pelletization Process of Postproduction Plant Waste. Int. Agrophys. 2012, 26, 279-284. [CrossRef]

10. Obidziński, S. Ocena Właściwości Energetycznych Odpadów Melisy. Zesz. Probl. Nauk Rol. 2010, 546, 253-262.

11. Obidziński, S.; Dołżyńska, M.; Kowczyk-Sadowy, M.; Jadwisieńczak, K.; Sobczak, P. Densification and Fuel Properties of Onion Husks. Energies 2019, 12, 4687. [CrossRef]

12. Dołżyńska, M.; Obidziński, S.; Kowczyk-Sadowy, M.; Krasowska, M. Densification and Combustion of Cherry Stones. Energies 2019, 12, 3042. [CrossRef]

13. International Organization for Standardization. PN-EN ISO 17828:2016-02 Solid Biofuels—Determination of the Bulk Density in Solid Biofuels; ISO: Geneve, Switzerland, 2016.

14. International Organization for Standardization. PN-EN ISO 17831-1:2016-02 Solid Biofuels—Mechanical Evaluation of Pellets and Briquettes_Part 1: Pellets; ISO: Geneve, Switzerland, 2016.

15. International Organization for Standardization. PN-ISO 1928:2020-05-Solid Fuels—Determination of Heat of Combustion by Calorimetric Bomb Method and Calorific Value Calculation; ISO: Geneve, Switzerland, 2020.

16. Obidziński, S.; Piekut, J.; Dec, D. The Influence of Potato Pulp Content on the Properties of Pellets from Buckwheat Hulls. Renew. Energy 2016, 87, 289-297. [CrossRef] 
17. Obidziński, S. Odpady Pochodzenia Roślinnego i Metody Ich Zagospodarowania. In Proceedings of the Technique of Environment Protection: TOP'2004, Častá-Papiernička, Slovakia, 30 June-2 July 2004. Bratislava, s. 245-250.

18. Denisiuk, W. Brykiety/pelety ze słomy w energetyce. Inż. Rol. 2007, 11, 41-47. 